https://helda.helsinki.fi

\title{
Manufacturing saltpetre in Finland in the late 16th and early 17 th centuries
}

\section{Lappalainen, Mirkka}

Helsinki University Press

2021

Lappalainen, M 2021, Manufacturing saltpetre in Finland in the late 16th and early 17th centuries . in P Talvitie \& J-M Granqvist (eds), Civilians and military supply in early modern Finland . Helsinki University Press , Helsinki , pp. 151-176 . https://doi.org/10.33134/HUP-10

http://hdl.handle.net/10138/340906

https://doi.org/10.33134/HUP-10

cc_by_nc

publishedVersion

Downloaded from Helda, University of Helsinki institutional repository.

This is an electronic reprint of the original article.

This reprint may differ from the original in pagination and typographic detail.

Please cite the original version. 


\title{
Manufacturing Saltpetre in Finland in the Late 16th and Early 17th Centuries
}

\author{
Mirkka Lappalainen \\ University of Helsinki
}

Gunpowder was essential for early modern warfare. Without it, it would have been impossible to increase firepower, develop weaponry and equip the ever-growing mass armies. Scarcity of gunpowder would have been fateful for a ruler who wanted to take part in the wars in Europe or in the battle for the dominion of the seas. The rulers of the Swedish Realm shared this problem, as its rise to a north European great power would not have succeeded without an adequate and reliable supply of gunpowder.

The making of gunpowder (black powder) was not in itself especially complicated. It was manufactured by mixing and grinding together coal, sulphur and potassium nitrate, also known as saltpetre. Coal and sulphur were easily obtainable and relatively cheap

\section{How to cite this book chapter:}

Lappalainen, Mirkka (2021). Manufacturing saltpetre in Finland in the late 16th and early 17th centuries. In Petri Talvitie \& Juha-Matti Granqvist (Eds.), Civilians and military supply in early modern Finland (pp. 151-176). Helsinki University Press. DOI: https://doi.org/10.33134/HUP-10-5 
ingredients. The problem was potassium nitrate, the key ingredient, as black powder was $67-75 \%$ saltpetre. ${ }^{1}$ Saltpetre could be bought from dealers in the great merchant cities such as Amsterdam and Danzig, but imports were expensive and uncertain, especially in times of war - in other words, most of the time. ${ }^{2}$ The rulers and their armies could not rely on such a risky method to obtain a product that was necessary for their existence. Historian David Cressy has compared saltpetre with oil and uranium in the modern world: no realm or country could exist without it, and the quest for saltpetre was an ongoing task for every king and government up until the development of modern explosives. ${ }^{3}$

Luckily, saltpetre could be also produced locally by extracting it from the most mundane of ingredients: dung and urine-soaked soil, straw and ash. The required raw materials were seemingly low-cost and abundant, but production was logistically difficult to organise, very slow, and labour-intensive.

This chapter studies how the manufacturing of saltpetre was organised in Finland in the late 16th and early 17th centuries, specifically from the Peace of Teusina in 1595 to 1629, when all the saltpetre works in Finland were leased out to a private entrepreneur. This was a key period of Swedish state-building and laying the foundation of the military great power it would become. During this period, the Swedish Realm waged wars against Russia in the east and against Poland in Prussia and in today's Baltic countries. This made Finland a strategically important area due to its central location, crucial to the upkeep of armies in the field. Finland also played an important role in the Swedish Civil Wars in the 1590s and experienced a bloody peasant war in 1597, because it formed the base of support for the displaced King Sigismund. In these turbulent times, the production of saltpetre in Finland was very important.

\footnotetext{
${ }^{1}$ Kiuasmaa 1962, p. 361.

${ }^{2}$ Uola 1998; Cressy 2013, pp. 90-91; Parrott 2015, pp. 198-199, 214-215.

${ }^{3}$ Cressy 2013, pp. 1-2.
} 
The early phase of Finnish saltpetre manufacturing was exceptional for both the means of production and for the active involvement of civilians. The crown owned and operated fairly large saltpetre factories, to which the peasants were obliged to deliver enormous quantities of raw material. By 1634, the crown had already changed the 'saltpetre tax' to a monetary payment, and peasants were no longer obliged to supply dirt and wood to the factories. After the Peace of Westphalia (1648), the need for gunpowder diminished and the required saltpetre could be imported from abroad. During the late 17th century, the production of saltpetre was revived, but now the system was based on itinerant workers, who travelled around with their equipment. ${ }^{4}$

This study shows how difficult saltpetre production was to organise in times of primitive administration. Although royal statutes were clear, they could not be put into action. There were problems with obtaining raw material, acquiring and maintaining equipment, and distributing the saltpetre itself. The production system could not meet the demands of the constant level of warfare, and therefore it is easy to understand why it had to be reorganised. The necessity of supplying raw materials and equipment made the factories an integral but disliked and somewhat obscure part of their local communities and the broader power structure.

Late 16th- and early 17 th-century Finland was a sparsely populated, cold and economically underdeveloped land that relied on a fragile agricultural system. Towns were few and small, and the huge inland tracts were covered with forests and swamps. Finland was, however, geopolitically important because of its proximity to the Russian and Livonian fronts. The coastal areas were buzzing with activity, and the Gulf of Finland in particular was filled with maritime traffic. This formed the local scene where saltpetre factories were established. In practice, they were the first industrial ventures established in the Finnish countryside.

${ }^{4}$ Haggrén 2007; Uola 1998, p. 19. 


\section{Previous Research and Sources}

In the late 1930s, Finnish historian Kaarlo Blomstedt complained that, despite saltpetre production's huge importance for the state and its impact on Finland, historians had not taken an interest in studying it. ${ }^{5}$ Eighty years later, the situation is still much the same. The general picture is still very incomplete, especially concerning the 'golden age' of saltpetre works, the first decades of the 17 th century.

The manufacturing of saltpetre has not been a core interest for economic or military historians - in Finland, Sweden or anywhere else. Whereas the history of mining or the manufacturing of guns has been researched extensively, the mundane process of making potassium nitrate has been almost forgotten. In Finland, the saltpetre production was hugely important in its own time, but it was also a dead-end industry - it did not develop into a more modern system. For the historians studying agrarian history and peasant societies, the production of raw materials for the factories has been a side note and seen as just another burden for the commoners. On the other hand, saltpetre has also been a side note for military historians studying the development of artillery. In recent international research, however, scholars have taken an interest in the economic and logistical aspects of military history, thereby bringing saltpetre into limelight. David Parrott writes about saltpetre as part of the international trade in army supplies in his Business of War (2012), and John Cressy focuses on England in his book Saltpeter: Mother of Gunpowder (2013).

The oldest work on the saltpetre industry and saltpetre tax in Finland is K. R. Melender's extensive study about taxation in Finland from 1617 to 1634 (1894). After Melender, it was Kaarlo Blomsted who next studied the topic and published an article (1939) about saltpetre administration in the 16th century. In 1962, Kyösti Kiuasmaa published a large volume about 16thcentury officials and other employees of the crown, also including

${ }^{5}$ Blomstedt 1939, p. 195. 
the manufacturing of saltpetre. After these earlier 'classic' works, the industry was more recently researched by Georg Haggrén in connection with the archaeological study of the royal mansion and related saltpetre works in Perniö (1997). Recently, the production of saltpetre has been touched upon by Suvianna Seppälä in her dissertation (2009) concerning different forms of taxation from 1539 to 1609 . In addition, there is Mikko Uola's non-academic but well-researched book about the history of explosives in Finland (1998). Saltpetre production has also been studied as a part of local history.

In Sweden, most of the few studies that concern saltpetre deal with the 18th and 19th centuries, local history, or the history of artillery, and are not especially relevant to this chapter.

In the late 16th and early 17th centuries, the administrative system of the Swedish Realm was still in its infancy. Documents considering saltpetre are fragmentary and scattered in different archives and collections. The bailiffs' accounts at the National Archives of Finland hold a variety of papers primarily dealing with factories' expenses, which were compensated from tax revenues (including, most importantly, wages). In the late 16th century, Finnish saltpetre works were in principle directly under the control of the Chamber, but apparently this system had its faults, because in 1602 King Charles IX (Sw. Karl IX) ordered that the bailiffs must include the saltpetre tax and related payments in their accounts. In practice, the bailiffs did this very haphazardly. The bailiffs' accounts from the 1610s and 1620s include receipts from saltpetre workmen, brief remarks about production amounts, and sometimes information about the saltpetre tax paid by the peasants, but not the accounts of the works themselves. ${ }^{6}$

The Lagus Collection (Sw. Laguska samlingen) at the National Archives of Finland is a somewhat strange entity formed by a

${ }^{6}$ The fragmentary nature of the archive material may have a connection to the intermittent history of the chamber's sub-division in Finland, the Turun laskukamari, which operated intermittently in the 16 th and 17 th centuries. 
notorious 19 th-century history enthusiast, C. G. Lagus. It includes a volume about the mining industry, containing dozens of letters and other documents about saltpetre production. In addition to the Lagus Collection, other records in the National Archives of Finland have also been used in this study, mainly the district court records ${ }^{7}$ and the Acta Historica. The royal statutes and letters about saltpetre manufacturing play a central role in this research. Among the otherwise fragmentary material, they present themselves as a clear and well-preserved body, recorded in the Collection of King's Letters (Sw. Riksregistratur) at the National Archives of Sweden. Most of these were printed in the 19th century in the so-called Waaranen's source editions.

In general, most of the sources offer information about how expensive and labour-intensive it was to run these factories: there is information about wages, buildings, and the raw material that local peasants had to deliver to the factories. There is also information about official plans and proceedings: how the crown wanted these factories to work. For the most part, however, these sources lack information about production amounts, delivery and the logistics of the actual production. Either this information was never documented or the documents have disappeared.

\section{Kings and Saltpetre}

During the 16th century, gunpowder changed from an expensive curiosity into a military necessity. The increasing role of firepower in warfare meant an increasing need for saltpetre. From 1570 to 1595 , Sweden was waging constant war with Russia, but the process of manufacturing saltpetre was still in many ways unestablished. There were numerous small saltpetre works, and gunpowder was made in mills close to the front. ${ }^{8}$ This system was primitive and could not meet the demands of expanding warfare. In 1593 Bengt

\footnotetext{
${ }^{7}$ In order to find court cases related to saltpetre, an old index of keywords ('Tuokko') has been used.

${ }^{8}$ Kiuasmaa 1962, p. 361.
} 
Söffrinsson Juusten, who was responsible for the artillery, wrote a letter to his brother-in-law, a bailiff in the south of Finland, underlining the importance of making steel bows. 'Bowmen do not need gunpowder or lead, which are so scarce in this Realm and cannot be obtained without great cost.'9

King John III (Sw. Johan III) made several efforts to develop saltpetre production and bring it under closer control. He appointed superintendents whose responsibility was to invent equipment and compile reports of production and costs. In 1581 Finland was designated as its own saltpetre manufacturing district. The king ordered every medium-sized farmhouse to deliver to its local saltpetre work five barrels of dirt, two barrels of sheep or goat dung, firewood, straw and ash. This saltpetre tax was a huge burden for the peasants. ${ }^{10}$

King John died in 1593 and was succeeded by his son Sigismund, who was already king of Poland. Sigismund, a Catholic, was challenged by his uncle, Duke Charles (Sw. Hertig Karl), a devout Protestant who was widely considered a potential usurper. Sigismund remained in Poland, and his most loyal servant in the Swedish Realm was a military chief named Klaus Fleming, the commander of Finland. In 1595, the Peace of Teusina ended the long feud between the Swedes and the Russians. However, Fleming was convinced that Duke Charles wanted to overthrow his master and did not want to demobilise the troops in Finland. He was preparing for a civil war. ${ }^{11}$

Saltpetre was a problem for Fleming's armament project. Besides cavalry, footmen, artillery, ships and swords, he needed gunpowder. It was unlikely that Fleming would get it from Sweden, as it was practically ruled by Duke Charles, who naturally opposed Fleming's armament. Bengt Juusten, now steward of Turku Castle

\footnotetext{
${ }^{9} \mathrm{KA}$, the Lagus Collection, VARIA, 4 Vuorityö (1592-1683), Bengt Juusten to Lydig Henriksson, 10 May 1593.

${ }^{10}$ Seppälä 2009, pp. 223-224.

${ }^{11}$ Lappalainen 2009, pp. 128-166.
} 
and Fleming's loyal servant, ${ }^{12}$ was familiar with this problem. In November 1595 he sent similar letters to the bailiffs of Ostrobothnia and southern Finland. The former letter complained that the equipment of the Voitby saltpetre factory in Ostrobothnia was in bad shape, whereas the latter expressed similar complaints about a factory in Perniö on the south-west coast of Finland, where the manager had complained that he and his workmen had not got enough help and food. Otherwise, the letters were almost exact copies of each other.

For Juusten and Fleming, the problem was the Peace of Teusina. Without a declared state of war, it was difficult to motivate anyone to take part in the making of gunpowder. Juusten wrote that, although God had mercifully given them peace, almost all their saltpetre had been used during the long war. Another problem was raw material, as only half of the bailiff's district supplied material for the factory each year.

According to Juusten, about 'ten or twenty thousand skeppund saltpeter' should always be stored in the artillery magazines, an absurd amount considering that one skeppund is equivalent to $170 \mathrm{~kg} .{ }^{13}$ Now, however, the magazines were almost empty. It is unclear if he was referring to the artillery magazine in Stockholm or in Turku, but his objective was nevertheless to obtain saltpetre and gunpowder for Fleming's troops in Finland. Juusteen wrote that he had discussed with Fleming about what actions might be necessary in this case - a threatening note, for Claus Fleming was a notoriously ruthless character. ${ }^{14}$

The civil war ended in the victory of Duke Charles. In the autumn of 1599, he conquered southern Finland, imprisoned or executed his opponents, and replaced them with his own loyal men. Curiously enough, his servants, led by Admiral Jochim Scheel, were

12 Syrjö 2002.

${ }^{13}$ Svenska Akademins ordbok SAOB [skeppund].

${ }^{14} \mathrm{KA}$, the Lagus Collection, VARIA, 4 Vuorityö (1592-1683), Bengt Juusten to Thomas Jörensson, 24 November 1595; Bengt Juusten to Jören Ollsson, 24 November 1595. 
faced with the same problem as Bengt Juusteen: there was no saltpetre in the Turku Castle. The duke had ordered them 'both by word of mouth and in writing' to investigate the situation regarding saltpetre manufacturing in Finland. The bailiffs again received letters, this time from the new rulers. In these letters, they were ordered to make sure that the statutes of John III were followed. ${ }^{15}$

In 1604, Duke Charles was crowned and became King Charles IX. He was a hard, suspicious and despotic ruler whose goal was to build a strong and loyal government. However, his ambitions were constantly thwarted by lack of means, information and workforce. His style was to send furious letters to the crown's servants and demand efficiency and loyalty. Still, little was done. The administrative system was primitive, and it was easy to ignore letters from Stockholm. ${ }^{16}$

Naturally, Charles's demands for control extended to saltpetre and its production. On a visit to Finland in the winter of 1602 he had made a declaration on the manufacture of saltpetre in this part of his realm. In the opening chapter, he declared that there had been no regulations at all about the making of potassium nitrate in Finland. According to the (then) duke, this had led to mismanagement and abuse. Saltpetre makers had servants who bullied peasants and demanded too much raw material, building material and firewood. Still, 'just a little or nothing' was eventually produced for the crown's purposes. ${ }^{17}$

Charles IX was accustomed to blame his servants' laziness and lack of loyalty for all his misfortunes, and the production of saltpetre was no exception. According to the king, the low production rates were due to the laziness of the manufacturers, as well as their habit of secretly selling potassium nitrate for their own profit.

${ }^{15}$ KA, the Lagus Collection, VARIA, 4 Vuorityö (1592-1683), Axel Ryning's, Jochim Scheel's and Tönne Jöransson's letters to Daniel Johansson, Jacob Nilsson and Jöran Bertilsson, 21 February 1600; Lappalainen 2009, pp. 247-249.

${ }^{16}$ Lappalainen 2014, pp. 34-39.

${ }^{17}$ Ordningh huru med Saltpetter bruken her i Finlandh skall holles. RA RR, 28 January 1602. Printed in Waaranen II, pp. 238-240. 
It is impossible to know whether this actually happened or if it was just a part of the king's rhetoric. The selling of potassium nitrate would have required markets and complicated networks, and someone willing to buy it. European rulers and armies were in constant need of gunpowder, but it is not likely that some producer in a remote Finnish village would have managed to sell it to a foreign agent. Bailiffs and other servants were often accused of selling tax products; however, it was much easier to sell barrels of grain than potassium nitrate, for which the common people had no use. There is one letter, written in 1594, where a man named Sigfrid Olsson talks about the two barrels of saltpetre he was willing to sell for eight barrels of rye. However, this document has been preserved out of its original context, and it is not possible to know what kind of 'deal' it actually was about. ${ }^{18}$

The reign of Charles's son Gustavus Adolphus (Sw. Gustav II Adolf) (1611-1632) was a period of growing warfare and intense state-building. The Swedish Realm was engaged in wars with its archenemies Denmark, Poland and Russia. Eventually, Gustavus Adolphus's troops also took part in the Thirty Years War in Germany. The growing scale of warfare meant an escalating need for weapons, guns and gunpowder. In 1616 Gustavus Adolphus was forced to double the amount of raw materials and firewood peasants had to deliver to saltpetre factories. He ordered Finnish bailiffs to make clear how transport to each factory would be arranged. He also reminded them that saltpetre production according to the receipts from manufacturers - had to be included in the bailiffs' accounts. ${ }^{19}$

During the reign of Gustavus Adolphus, the crown leased out various sectors and sections of economic life, such as ironworks or the right to collect certain customs or taxes. It was not an ideological privatisation but rather a way to guarantee a steady flow of cash and liberate the crown from laborious and risky

\footnotetext{
${ }^{18}$ KA, Lagus Collection, VARIA, 4 Vuorityö (1592-1683), Sigfrid Olsson to Jören Ollsson, 19 August 1594.

${ }^{19}$ RA RR 27 February 1616; Waaranen V, p. 109.
} 
responsibilities. The crown also began to lease out saltpetre works, and finally in 1629 a wealthy merchant named Jacob Wolle became the leaseholder of all the saltpetre factories of Finland. He leased the factories up until 1635, when all the saltpetre and gunpowder factories in the whole realm were leased out to a Frenchman named Fermin Mazalet. $^{20}$

These leasing systems had already brought about numerous conflicts and suspicions of misuse in the $1620 \mathrm{~s}^{21}{ }^{11}$ Recurring problems and low productivity were probably the main reasons why the saltpetre tax was soon changed to a money payment.

\section{Organising the Production}

Saltpetre factories were fairly large compounds by 16th- and 17thcentury Finnish standards. They consisted of several buildings and were sites of constant activity. They had to be located near waterways, both because good delivery routes were necessary, and because the industrial process itself required water. The staff consisted of the factory foreman (Sw. saltpeter sjundare), his clerk, and the workmen, the number of whom depended on the size of the factory. ${ }^{22}$

When John III ascended the throne in 1560, there were five saltpetre factories in Finland. During the Russo-Swedish War of 1570-1595, when gunpowder was needed in the eastern and southern borders of the realm, their number rose to 16 or 17 . According to Kyösti Kiuasmaa, these 'factories' were mostly very small, and there were breaks and discontinuity in their operations. In the 1580 s they produced just 1.5-5 skeppund (170 kg) of saltpetre per year, with total production being 18 skeppund. By 1592 total production had risen to 55 skeppund, and the factories' individual production rates were 4-6 skeppund. ${ }^{23}$ It would

\footnotetext{
${ }^{20}$ Kerkkonen 1947, p. 165.

${ }^{21}$ Melender 1896, pp. 419-420; Haggrén 1997, p. 166.

22 Kiuasmaa 1962, p. 363.

${ }^{23}$ Kiuasmaa 1962, pp. 362-363.
} 
have taken 200-300 years to meet Bengt Juusteen's demand of a 10,000-20,000 skeppund saltpetre storage.

Known saltpetre factories were scattered around south and south-west Finland. In the 1590s, the largest factory was at Naantali in the south, with Moisio in the east and Voitby in the north following. During the first decades of the 17 th century the number of saltpetre manufacturers plummeted, and production was concentrated in somewhat larger facilities (see Figure 5.1). In 1626, before Jacob Wolle took over saltpetre production in Finland, there were nine factories: Naantali, Ulvila, Perniö (Näse), Sipoo (Löparö), Hollola, Sääksmäki (Voipaala), Rantasalmi, Moisio and Viipuri. ${ }^{24}$ For some reason, production at Mustasaari (Voitby) was temporarily halted, but started again later.

Essentially, there were two factors that dictated where factories were established: raw material and access. The amount of soil and organic waste needed was so massive that saltpetre factories had to be close to populated areas. They had to get their supply from their surroundings, without need to transport the raw material from too far. Furthermore, the manufactured saltpetre had to be shipped to wherever it was needed. The first precondition posed a problem, as Finland was a huge, mostly desolated country with long distances between settlements. Factories had therefore to be scattered around the country. Luckily, delivery routes were not a problem, as the long coastline and many lakes and rivers formed an extensive network of water transportation. In wintertime, the country was likewise crisscrossed with icy routes over the frozen, snowy landscape.

Early 17th-century saltpetre factories were all located near good waterways: Hollola, Sääksmäki, Moisio and Rantasalmi by lakes and inland water routes, Ulvila and Voitby by large rivers, and Naantali, Perniö, Sipoo and Viipuri close to the sea. The site of Löparö in Sipoo is a good example of an optimal location: it was on a large island by the shoreline, about $25 \mathrm{~km}$ from Helsinki. On the other side of the Gulf of Finland were the city of Tallinn and the fortress of Narva, an important Swedish outpost in wars with Russia and Poland.

${ }^{24}$ KA Bailiff's accounts, 418:156 (Ledgers for Finland 1626-1627). 


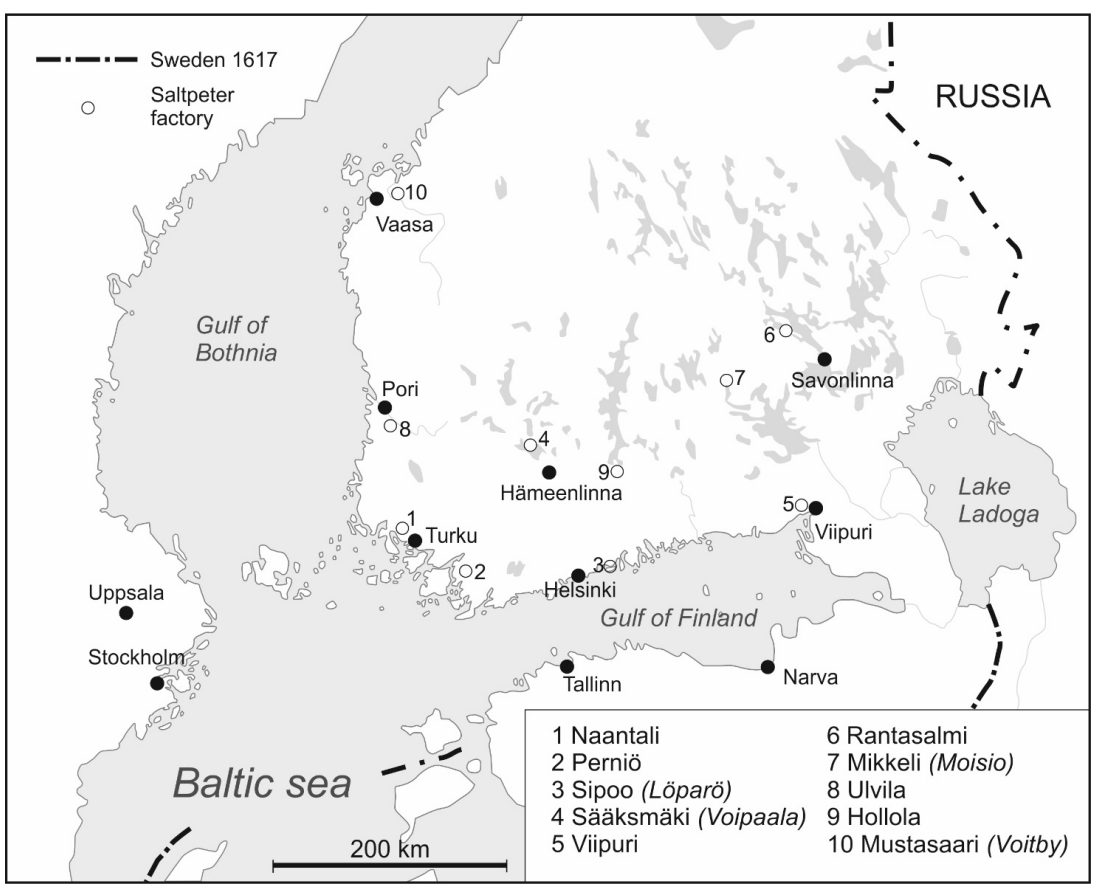

Figure 5.1: Saltpetre factories in Finland during the 1620s. Source: Map drawn by Petri Talvitie.

The process of making saltpetre was slow and labour-intensive. First, the urine-soaked soil, rich in nitrates, was heaped up with rotten grass and hay, slaughter waste, dung, straw and sticks. These piles of soil were left to 'brew up' for two or three years, moistened and turned over at regular intervals. Then, this heap of soil was mixed with ash and laid in wooden tubs upon stacks of straw. Boiling water was added, and after 10-12 hours the mixture was drained from a hole in the tub's bottom. This liquid was now boiled in large, heavy copper bowls called pans. The boiling took several days and was the heart of the process. The ensuing vaporisation resulted in granulated raw saltpetre, which was then dried and eventually purified by heating, dissolving in water, and filtration. ${ }^{25}$

Saltpetre factories consisted of several buildings, because every part of the manufacturing process required its own structure.

${ }^{25}$ Uola 1998, p. 17; Soininen 1954, p. 188. 
First, the soil and ash were stored in separate barns. The soil and ash were then diluted with boiling water in an 'ash house, and the slow boiling itself, as well as the drying, were done in separate buildings. In addition to these buildings, there were the normal stables, barns and houses for the workmen, animals and foodstuff. ${ }^{26}$

Löparö in Sipoo, on the southern coast of Finland, is the only saltpetre factory that has been archaeologically investigated. The remains are located on a small hill, and consist of various bare stone constructions, earthen banks, and ditches. There are two large pits that are surrounded by earthworks, and inside them there are remains of three drystack furnaces. ${ }^{27}$ In the 16th and early 17 th centuries Finland practically all buildings were made of pinewood and did not even have stone foundations. Compared with an ordinary farmhouse, the Löparö factory was in other words very robust.

The factories were in constant need of building material: timber, bricks, mortar and iron. The buildings had to be in relatively good condition and provide shelter from rain, sleet and snow. This was, however, by no means self-evident. In 1603, Duke Charles sent his servant to Finland to make sure that the necessary houses were built in saltpetre factories, so that work could go on 'during winter and in the summer. ${ }^{28}$ This turned out to be easier said than done. In 1623 Carl Carlsson Gyllenhielm, one of the leading Swedish aristocrats, was sent to Finland to inspect the economic situation and military administration. He also took an interest in saltpetre manufacturing. In his report, Gyllenhielm wrote that that many of the saltpetre works' buildings had been 'derelict' and were now being rebuilt. He also wrote that the saltpetre works urgently

${ }^{26}$ Haggrén 1997, pp. 164-167.

${ }^{27}$ Finnish Heritage Agency, Guide for archaeological cultural heritage: Salpietarikeittimö. http://akp.nba.fi/wiki;salpietarikeittim\%C3\%B6; Register of protected heritage sites: Löparö. www.kyppi.fi/to.aspx ?id=112.1000010857.

${ }^{28}$ KA, the Lagus Collection, VARIA, 4 Vuorityö (1592-1683), Carl IX 30 August 1603, signed by Erik Eriksson. 
needed new copper 'pans', for they were in general old and in poor repair. ${ }^{29}$

Copper 'pans' (also called tubs) were the most valuable equipment in a saltpetre factory. Owing to their heavy use and the constant heat, the pans often broke and had to be fixed or replaced. Repairing broken pans and acquiring new ones was a constant problem that appears in the records repeatedly. Copper was expensive, and the shaping had to be done by skilled coppersmiths. In 1623 it was reported that a coppersmith in Turku had held onto one of the Naantali factory's pans for a year and a half as a security for his unpaid wages. ${ }^{30}$

Pans were large and weighed several hundred kilograms, which meant that they were hard to move. In 1617 the Sääksmäki factory, then the largest, needed a new pan. It took four men six weeks to prepare. ${ }^{31}$ They were often made of miscellaneous confiscated items, such as stills that were used in distilling alcohol. ${ }^{32}$ They were also so valuable that at the Sääksmäki factory it was decided that the pans belonged to specific administrative areas (Satagundz Panna etc.). In other words, it was the local bailiff's duty to take care that the pan was in good condition. ${ }^{33}$

In order to then make gunpowder, saltpetre had to be mixed and ground up with sulphur and charcoal. This was done in special 'mills'. During the Russo-Swedish War of 1570-1595 these mills

${ }^{29}$ RA, Archives of the Chamber (Kammarkollegiet ämnessamlingar), Bergsbruk 1592-1719, vol 133, Strödda bergverksakter 1620-1719, Hwad som widare öffuer min Instruction effter (...), undated, circa 1623.

${ }^{30} \mathrm{KA}$, the Lagus Collection, VARIA, 4 Vuorityö (1592-1683), Carl Carlsson Gyllenhielm to Joen Mårtensson, 25 June 1623; about payments to coppersmiths see also KA 3579:31 (Porvoo); 3607:36 (Porvoo); KA 4897:65 (Etelä-Pohjanmaa).

${ }^{31} \mathrm{KA}$, the Lagus Collection, VARIA, 4 Vuorityö (1592-1683), Erik Axelsson's receipt, 17 April 1616.

${ }^{32}$ Uola 1998, p. 17.

${ }^{33}$ KA, the Lagus Collection, VARIA, 4 Vuorityö (1592-1683), Bertil Michilsson 7 July 1597. 
were located closer to the front, ${ }^{34}$ but during the next century the making of gunpowder was concentrated in factories in Sweden. In general, it was easier to stock and transport potassium nitrate than gunpowder, because the latter had to be carefully protected from damp. ${ }^{35}$ Stocking gunpowder was also hazardous: a tiny spark could blow up an entire magazine or even a battleship.

Fragmentary sources show that in the early 17 th century saltpetre was delivered to various places, probably where it was most needed at the moment. The logistics of saltpetre transportation were clearly not planned beforehand and seem almost haphazard. It was logical to deliver saltpetre from Naantali to the nearby Turku Castle, as well as from the Viipuri factory to the local castle, ${ }^{36}$ but there were also other solutions. In 1609 a man named Jöns Pedersson travelled from Turku Castle to Stockholm 'with the saltpeter.' ${ }^{37}$ Two years later, someone named Bastian Melchersson was sent to Finland to visit the factories and 'collect the saltpeter here in Finland to Sweden. ${ }^{38}$

In the summer of 1613 the saltpetre manufacturer in Korsholm delivered $365.5 \mathrm{~kg}$ of saltpetre to the arsenal in Stockholm and circa $340 \mathrm{~kg}$ to Turku Castle. ${ }^{39}$ In the summer of 1614, 4 skeppund $(680 \mathrm{~kg})$ of saltpetre was delivered from Korsholm to Viipuri. ${ }^{40}$ This is remarkable because of the extreme distance between Korsholm, on the west coast, and the town of Viipuri, in the southeast of Finland by the Russian border. In those days, the Swedish Realm was at war with Russia and intervened in the struggle for the czar's throne. It was thus natural that saltpetre production in

\footnotetext{
${ }^{34}$ Kiuasmaa 1962, p. 361.

${ }^{35}$ Uola 1998.

${ }^{36}$ KA Bailiff’s accounts, 1706:28 (Masku); 5985:13 (Jääski); 5966:13 (Lappee); 5950:25 (Ranta).

${ }^{37}$ KA Bailiff's accounts, 1710:73 (Turku castle).

${ }^{38}$ KA Bailiff's accounts, 6751:27, 6752:158 (Pien-Savo).

${ }^{39}$ KA Bailiff's accounts, 4879:25 (Korsholma and Etelä-Pohjanmaa).

${ }^{40}$ KA Bailiff's accounts, 4897:64 (Etelä-Pohjanmaa); see also KA 1710:73 (Turku castle and its estates).
} 
the eastern part of Finland did not meet the demands of the geopolitical situation.

Although several of the saltpetre factories were established close to different castles and larger cities, it seems that their product was shipped unsystematically wherever it was needed. To send someone from Sweden to collect saltpetre from the Finnish factories and travel with it to Stockholm does not sound sensible at all because of the excruciatingly long distances. It would have taken weeks or months to complete even a part of this task. In summary, saltpetre distribution reflects the problems of early 17th-century administration in general: the lack of personnel, established administrative practices and reliable information caused enormous difficulties.

\section{Conflicts - Materials, Wages and Local Power}

In principle, it was the local bailiff's duty to ensure that the saltpetre works received enough raw materials. The bailiff and his men worked as intermediates between the peasants and the saltpetre works. Sometimes the bailiff and his men took care of collecting and delivering the raw materials, while in other cases it was the duty of the factory workmen.

The factories needed huge amounts of material. For instance, in 1624 the Moisio factory required over 1,446 barrels of dirt and sheep manure and 99 barrels of ash from the district of Pien-Savo. During the same year, 2,131.5 barrels of dirt and sheep manure and over 266 barrels of ash were supplied to Moisio from the larger administrative district of Suur-Savo. ${ }^{41}$ In 1620 no fewer than 3,522 barrels of dirt and over 220 barrels of ash were taken to the Löparö factory from the surrounding administrative district of Porvoo. In addition, peasants provided the factories with enormous amounts of firewood, straw and other raw materials. The deliveries made by the peasants were seemingly registered in

${ }^{41}$ KA Bailiff's accounts, 6801:24v (Pien-Savo); KA 6800:17 (Suur-Savo); see also KA 6791:22 (Pien-Savo). 
the bailiff's accounts on a random basis; for instance, in 1620 there is no mention of the saltpetre tax in the district of Kymeenkartano beside Porvoo, although it is not possible to know whether the tax was actually not collected or just not registered. ${ }^{42}$

In principle, no one was free from the saltpetre burden. Noblemen's mansions were normally free from taxes, but even they had to provide dirt to the factories. In reality, all sorts of defaults and exceptions were made. This caused disagreements and conflicts, especially after Wolle took over the saltpetre works. He soon noticed that there were people who routinely dodged the payments, and that large districts, such as the Åland archipelago, did not pay any saltpetre tax at all. ${ }^{43}$ However, Wolle's complaint is odd, because in the years prior the payments of the saltpetre tax were carefully registered in the bailiff's accounts of Aland. ${ }^{44}$

By today's standards, it seems that saltpetre was made of waste and garbage. In the early modern world, however, things like abattoir waste, muck and urine were valuable. Lack of manure was a life-threatening problem for agriculture in Finland. It was a vicious cycle: meadows did not produce enough fodder, so there were not enough cattle, and in turn not enough dung. Lack of manure made crops susceptible to frost and wet, which in turn caused harvest failures. Peasants were constantly threatened by food shortages and famines. ${ }^{45}$

Although the duties of the peasants were carefully listed in the royal statutes pertaining to saltpetre, it seems that practices and customs varied. The burden was not the same everywhere and depended on the bailiff's activity and the needs of the saltpetre factory in question.

${ }^{42}$ KA Bailiff's accounts, 3607:40 (Porvoo); KA 3606 (Kymenkartano), 3609 (Kymenkartano).

${ }^{43}$ Haggrén 1997, p. 165; Melender 1896, pp. 414-426.

${ }^{44}$ KA Bailiff's accounts, 2902:14v (Åland); 2904:13 (Åland); 2906:21 (Åland).

${ }^{45}$ Seppälä 2009, p. 224; Lappalainen 2012, pp. 47-55. 
The problems with raw material deliveries were foreseeable: insubordination, disobedience and loitering. In 1626 the saltpetre manufacturer of Viipuri went to the local court and demanded the dirt and ash the peasantry should have delivered. It turned out that many were so poor that they were unable to provide the factory with anything. ${ }^{46}$ One year later, the factory buildings were in such a derelict condition that they were in danger of collapsing. The local court had to order nearby peasants to fix them. ${ }^{47}$ The saltpetre maker was later also charged with hitting and abusing peasants. However, the claims were based on the testimony of only one man, who according to the jury was an old fool and not in his right mind. ${ }^{48}$

The problems in raw material deliveries had a direct effect to the livelihood of the manufacturers. According to the statutes established by Charles IX in 1602, saltpetre manufacturers were paid according to the amount of saltpetre produced, so that the larger factories were paid more than the smaller ones. ${ }^{49}$ Wages were marked in the crown's budget, ${ }^{50}$ but the manufacturer and his workmen were only paid after they had delivered the saltpetre to wherever it was needed. Records show that this royal order was generally abided by: the manager of the factory was only paid when he could prove that he had delivered the product to wherever it was needed. ${ }^{51}$ For example, in 1605 the saltpetre

${ }^{46}$ KA District court records, Jääski, Ranta and Äyräpää, Jääski and Ruoholahti 9 January 1623, p. 8.

${ }^{47}$ KA District court records, Jääski, Ranta and Äyräpää, Jääski and Ruoholahti 9 January 1624, p. 23.

${ }^{48}$ KA District court records, Jääski, Ranta and Äyräpää, Jääski and Ruoholahti 10 October 1624, pp. 35-36.

${ }^{49}$ RA RR 28 January 1602. Printed in Waaranen I, pp. 238-241.

${ }^{50}$ KA Bailiff's records, 397:57-58v (Payroll for the crown's servants).

${ }^{51}$ KA Bailiff's accounts, 4376:35v (Hollola and Hattula) 5985:13 (Jääski); 5966:13 (Lappee); 5950:25 (Ranta); 6624:29 (Suur-Savo); 6754:18 (Suur-Savo); 1706:27v (Masku); 4897:29v, 64 (Etelä-Pohjanmaa); 358:158 (Kokemäenkartano, Häme, Raasepori, Porvoo and Viipuri); 2900:14v (Åland). Sometimes the amount of saltpetre is not 
manufacturer of Rantasalmi could show the bailiff the receipt he had received from the arsenal in Viipuri. He had taken there circa $700 \mathrm{~kg}$ of saltpetre, and now the bailiff gave him (and his workmen) $891 / 4$ barrels of grain. ${ }^{52}$

This was not the standard practice in paying the wages of the crown's servants. For example, miners and prospectors were paid their wages whether they found anything or not. Mining was a hazardous activity, where no one could guarantee the results. Saltpetre manufacturing, on the other hand, was in principle controllable. Certain amount of raw materials and firewood meant a certain amount of the product. As a result, the system of tying payments to production linked the factories more closely with their local communities. If the manufacturers did not get enough raw materials, or if the equipment or buildings were in bad shape, the production would halt.

In principle it was the bailiff who was responsible for supplying the raw materials and other needs of the factories. It seems, however, that the saltpetre manufacturers sometimes had to take things in their own hands. In the 1620s the former saltpetre manufacturer of Ulvila was charged with malpractice: he had arbitrarily, without the authorisation of the bailiff, levied peasants for grain, butter and a sheep and was ordered to pay them back. He had also taken a large tub (pan) and had not paid for it. ${ }^{53}$

In the late 1610s the long-time manager of the Löparö factory died. His son and son-in law started to run the factory after him but were faced with a legitimacy problem. They had to prove that they were entitled to get deliveries of raw materials, and specifically according to the king's statute of 1616, which considerably increased the peasants' burden. Another problem was that

registered. From the bailiff's viewpoint it was essential to register what payments he had made from the tax revenues, not what the saltpetre makers had done with their product.

${ }^{52}$ KA Bailiff's accounts, 6709:12v (Pien-Savo).

${ }^{53}$ KA District court records, Ala-Satakunta, Ulvila 11 November 1625, pp. 237, 242v. 
the father had died before he had settled accounts with the local bailiff. As a result, the son and the son-in-law were forced to appeal to other authorities and write a kind of proclamation that was then read in all district court sessions in the administrative area. ${ }^{54}$

Saltpetre manufacturers lacked formal authority over the peasant community. They were not as frightening as the crown's bailiffs, who claimed taxes and employed thug-like servants to help them. It was easy to neglect the manufacturer's claims. In order to keep things going, saltpetre manufacturers had to rely on the bailiff and his men. The arbitrary actions of the saltpetre manufacturer of Ulvila can be explained by the fact that he was not on good terms with the local bailiff, and accused him of malpractice; according to the saltpetre maker, the bailiff had not correctly written down the amount of taxes he had paid. ${ }^{55}$

By the late 16th century, the kings had already started to appoint superintendents whose task was to control all the saltpetre works in Finland. Receipts signed by the inspectors indicate that they really travelled around and visited the factories. However, their ability to actually control the production must have been very limited, and the position was abolished in $1621 .{ }^{56}$

When the crown began to lease out saltpetre works, new problems began to arise. It was in the leaseholders' interest to make the production more effective and force the peasants pay their share. According to the contracts, the leaseholders undertook to deliver to the crown a certain amount of saltpetre in a year. It was no longer the bailiff who took care of collecting the raw materials from the peasants but the leaseholder and his men, who could be ruthless and were also accused of collecting too much tax. Some of the leaseholders did not even make any saltpetre: they collected the saltpetre tax in money and bought the saltpetre abroad,

${ }^{54}$ KA, the Lagus Collection, VARIA, 4 Vuorityö (1592-1683), Sigfred Bengtsson and Mårten Hansson, 12 January 1619.

${ }^{55}$ KA District court records, Ala-Satakunta, Ulvila 11 November 1625, p. 237.

${ }^{56}$ Melender 1896, p. 419. 
letting the factories decay. In the 1620s this was not allowed, for the crown still wanted to support domestic production. ${ }^{57}$

Saltpetre factories were industrial ventures situated in otherwise totally agrarian communities. Other than a few small mining ventures, one ironworks (Mustio), the crown's shipyards and the saltpetre factories, there really was no 'industry' in Finland at the time. Later in the 17th and 18th centuries, several mines, ironworks and timber mills were established around the country, but in the late 16th and early 17 th centuries such ventures were still largely non-existent. Even tar-burning was small-scale compared with the upcoming decades. In other words, saltpetre factories were oddities. Some two hundred years later Finnish peasants were obliged to make saltpetre themselves, and agents travelled around the country teaching them. ${ }^{58}$ In the late 16th and early 17 th centuries the peasants were probably not familiar with the process of making gunpowder out of dung. As a part of the war effort, saltpetre manufacturing was much less straightforward and less comprehensible than providing troops with food and accommodation.

\section{Conclusion}

In the late 16th and early 17 th centuries the crown tried to ensure the supply of Finnish saltpetre by means of strict orders and stateowned saltpetre works. This system replaced the more fragmented network of smaller manufacturers. Peasants were responsible for the delivery of raw materials, the amount of which was in principle clearly defined. The expected output of the saltpetre works was also predetermined. In reality, the situation was much more

${ }^{57}$ The National Archives of Sweden (RA), Archives of the Chamber (Kammarkollegiet ämnessamlingar), Bergsbruk 1592-1719, vol 133, Strödda bergverksakter 1620-1719, Hwad som widare öffuer min Instruction effter (...), undated, circa 1623; Melender 1896, pp. 418-421.

${ }^{58}$ Uola 1998, pp. 23-24. 
uncertain and chaotic - this kind of contradiction was essentially unavoidable in the early 17 th century, when logistic as well as administrative structures were still primitive. In 1629 the crown 'solved' the problems by leasing out Finnish saltpetre production.

Saltpetre works were difficult to run, because their output was dependent on the deliveries of raw materials. Peasants hated the 'saltpetre tax' because the raw materials, especially dung, were extremely valuable as manure. To get anything done, the saltpetre manufacturers had to have a good relationship with the local administration, in other words the bailiff and his men. The system was essentially oppressive. Peasants were forced to give up an important part of life-saving manure to feed the endless demands of warfare. Saltpetre works did not benefit them directly in any way. The works did, however, increase economic activity in their areas. Like any industrial venture, they created work, tasks, and logistical connections that that had not existed before. For example, someone had to make and repair the large copper pans the factories needed and was paid for it.

Saltpetre manufacturers were paid according to their output. In order to receive their wages, they had to deliver their product to wherever it was needed. For the crown's part this was almost a genius resolution to the problem of control: it was in the saltpetre manufacturers' interest to ensure that raw materials were delivered and that the buildings and equipment were in good shape. If the system did not work, the saltpetre manufacturers were not paid. This, however, resulted in conflicts with the manufacturers and local communities.

It is easy to overemphasise the failings in this saltpetre manufacturing system. Nevertheless, it worked well enough for decades, during times when the demand for gunpowder was constantly growing. However, more research should be done considering the actual logistics of gunpowder and the role of imported saltpetre in Gustavus Adolphus's army.

Saltpetre works were usually established by waterways in tiny villages, most of them far away from towns. They were the first industrial ventures in otherwise deprived agrarian communities. 
The making of saltpetre was in fact a complicated chemical process that was different from all the other 16th- and 17th-century industries, which consisted mostly of processing wood or iron. Commoners might not have liked this prelude to industrialisation, and for them the making of saltpetre was just one of the never-ending burdens of the constant warfare. Nevertheless, saltpetre connected Finnish peasants and craftsmen to the military revolution, and to the great changes occurring in the early modern world.

\section{Bibliography and Sources}

\section{Archival sources}

Riksarkivert [Swedish National Archives], Stockholm (RA)

Riksregistratur [Collection of Kings' Letters], available online in www.svar.se

Kammarkollegiet [Archives of the Chamber]

Ämnessamlingar

Bergsbruk 1529-1872 [Mining]

Vol. 133 Strödda Bergverksakter 1620-1719 [Miscellaneous documents]

Kansallisarkisto [National Archives of Finland], Helsinki (KA)

Acta Historica

$1600-1611$

Laguksen kokoelma [The Lagus Collection]

VARIA, 4 Vuorityö (1592-1683)

Voudintilit 1604-1627 [Bailiffs' Accounts], available online in www .digi.narc.fi

Masku

Porvoo

Hattula and Hollola

Pien-Savo

Korsholma and Etelä-Pohjanmaa

Lappee

Suur-Savo

Jääski, Ranta and Äyräpää

Åland

Turku Castle 1610 
Suomen pääkirjat 1626-1629 [Ledgers for Finland]

Suomen kruununmiesten palkkausluettelo 1623 [Payroll for the Crown's Servants]

Kihlakunnanoikeuksien renovoidut tuomiokirjat [District Court Records], available online at digi.narc.fi

Ala-Satakunta 1620-1625

Jäski, Ranta and Äyräpää 1623-1624

\section{Printed primary sources}

Waaranen, J. E. (1864, 1866, 1874, 1878). Samling af urkunder rörande Finlands historia II-V. Handlingar upplysande Finlands historia under Karl IX:s tid och Gustaf II Adolfs tid. Helsingfors: Finska Litteratur-Sällskapets tryckeri.

\section{Electronic sources}

Register of protected heritage sites. Helsinki: Finnish Heritage Agency. Available: https://www.kyppi.fi/palveluikkuna/mjreki/read/asp/r _default.aspx (accessed 20 October 2019).

Guide for archaeological cultural heritage. Salpietarikeittimö. Available: http://akp.nba.fi/wiki;salpietarikeittim\%C3\%B6 (accessed 20 October 2019).

Svenska Akademins ordbok. Available: https://www.saob.se (accessed 20 October 2019).

\section{Literature}

Blomstedt, Kaarlo (1939). Suomen järjestäminen omaksi salpietarinvalmistuspiiriksi. Historiallinen Arkisto, XLV, pp. 195-250.

Cressy, David (2013). The mother of gunpowder. Oxford: Oxford University Press.

Haggrén, Georg (1997). Perniön Näsen salpietarinkeittimö (1592-1640). In Marianna Niukkanen (ed.), Perniö - Kuninkaan ja kartanoiden pitäjä (pp. 163-172). Helsingin yliopiston taidehistorian laitoksen julkaisuja XV. Helsinki.

Haggrén, Georg (2007). Wolle, Jacob. Kansallisbiografia-verkkojulkaisu. Studia Biographica 4. Helsinki: Suomalaisen Kirjallisuuden Seura. Electronic edition. Available: http://urn.fi/urn:nbn:fi:sks-kbg-003909 (accessed 22 October 2019). 
Kerkkonen, Veikko (1947). Ruotsi-Suomen finansseista 1600-luvun alkupuolella. Historiallinen Arkisto, 52, pp. 141-212.

Kiuasmaa, Kyösti (1962). Suomen yleis- ja paikallishallinnon toimet ja niiden hoito 1500-luvun jälkipuoliskolla. Historiallisia tutkimuksia LXII. Helsinki: Suomen Historiallinen Seura.

Lappalainen, Mirkka (2009). Susimessu. 1590-luvun sisällissota Suomessa ja Ruotsissa. Helsinki: Siltala.

Lappalainen, Mirkka (2014). Pohjolan Leijona. Kustaa II Aadolf ja Suomi 1611-1634. Helsinki: Siltala.

Melander, K. R. (1896). Suomen ynnä Käkisalmen läänien ja Inkerin veroista vuosilta 1617-1634. Historiallinen Arkisto, XIV.

Parrott, David (2012). The Business of war. Military enterprise and military revolution in early modern Europe. Cambridge: Cambridge University Press.

Seppälä, Suvianna (2009). Viljana, nahkoina, kapakalana. Talonpoikien maksamat kruununverot Suomessa vuosina 1539-1609. Helsinki: Suomalaisen Kirjallisuuden Seura.

Soininen, Arvo M. (1954). Rantasalmen historia. Rantasalmi.

Syrjö, Veli-Matti (2002). Juusten, Bengt. Kansallisbiografia-verkkojulkaisu. Studia Biographica 4. Helsinki: Suomalaisen Kirjallisuuden Seura. Electronic edition. Available: http://urn.fi/urn:nbn:fi:sks-kbg -000536 (accessed 22 October 2019).

Uola, Mikko (1998). Räjähteet Suomessa. Historiaa mustasta ruudista 2000-luvulle. Räjähdeyhdistys. 